\title{
Paraganglioma of the Filum Terminale: An Extremely Uncommon Neuroendocrine Neoplasm Located in Spine
}

Sir,

Spinal paragangliomas are neuroendocrine tumors of the extra-adrenal paraganglioma system. Its occurrence is considered as uncommon within the spinal canal and commonly located as intradural mass lesion within the cauda equina. Paragangliomas originate from paraganglia, which are small spherical bodies measuring usually $<5$ $\mathrm{mm}$ in the diameter, containing neurosecretory vesicles with biogenic amines, for example, catecholamines, serotonin, and somatostatin peptides. ${ }^{[1]}$ Paraganglioma usually develops at the sites of normal locations of paraganglia, mostly in the abdominal cavity, carotid body, or glomus jugulare or rarely can also in other body parts. The majority of paraganglioma is benign and considered as 
nonfunctional but carries risk of malignant transformation. However, it can also be rarely associated with excess catecholamine production and secretion. ${ }^{[1,2]}$ Paraganglioma of spinal cord is uncommon lesion. Its occurrence is extremely rare, about 150 cases of spinal paraganglioma is reported in literature, mostly in the form of an isolated case reports. ${ }^{[1-5,7-21]}$ Authors report an interesting and unique case of paraganglioma developing in the filum terminale presented with progressive paraparesis.

A 40-year-old woman was admitted to our department with a history of low backache with radiating pain to right lower limb. The X-ray lumbosacral spine showed no evidence of scalloping of vertebrae [Figure 1]. The magnetic resonance imaging (MRI) of lumbosacral spine was carried out for further evaluation, which revealed the presence of an intradural tumor located at the L3 level, size of the lesion was $17 \mathrm{~mm} \times 6 \mathrm{~mm} \times 6 \mathrm{~mm}$ [Figures 2 and 3], which showed intense homogenously enhancement after gadolinium administration [Figures 4-6]. MRI myelogram clearly outlined the extent, relation to dura, nerve roots of cauda equina [Figure 7]. She underwent surgery under general anesthesia in prone position with image intensifier to localize appropriate vertebral level intraoperatively and underwent L2-3 laminoplasty and microneurosurgical total removal of intradurally located tumor. The lesion was oval in shape, soft bluish, densely adhered to the dorsal aspect of the dura, and contiguous spinal roots. Histological examination showed a typical picture of paraganglioma, composed of zellballen cells balls formed by nests of chief cells, separated from each other by fibrovascular septa. The chief cells had regular, round to oval nuclei, and abundant eosinophilic cytoplasm. There were scattered areas of hyalinization and fibrosis with secondary trabecular arrangement of tumor cells. There were no mitotic figures seen.

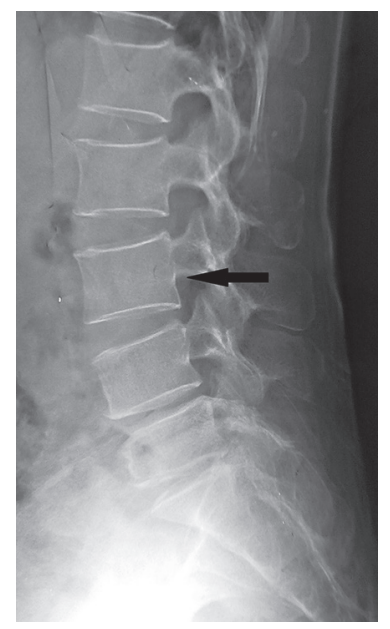

Figure 1: X-ray lateral view lumbosacral spine with no evidence of scalloping of vertebral body (arrow)
Paraganglioma are neuroectodermal tumors of the autonomic paraganglia, derived from the chromaffin cells of neural crest origin. ${ }^{[1]}$ Its occurrence within the central nervous system is unusual. Intracranially, paraganglioma was encountered in the sellar, pineal, and petrous ridge regions. ${ }^{[1,3,5]}$ Spinal cord paragangliomas are usually tend to occur at the end of the spinal column below L1 vertebral level, but less commoner sites include cervical and thoracic regions; however, most of the published cases were located at cauda equina or filum terminale. ${ }^{[1,2,5,6,10,12,15]}$ Paraganglioma occurring in the cauda equina represents approximately $3 \%-4 \%$ of spinal lesions. ${ }^{[2,10,17-21]}$

Interestingly, a series of thirty spinal paraganglioma, analyzed by Moran et al. in 1997, ${ }^{[7]}$ consisted of 19 lesions located in the lumbar region of the spine, another six in the cauda equina, two in the filum terminale, two in the thoracic, and the remaining one in the cervical region. Spinal paraganglioma is presumably derived from ganglion cells, normal paragangliomas associated with blood vessels or from residual peripheral neuroblasts, which can give rise to either chemoreceptor ganglion cells. ${ }^{[5]}$

Spinal paraganglioma usually presents with low backache with associated radiculopathy although sensory and motor deficit are uncommon. Bowel and

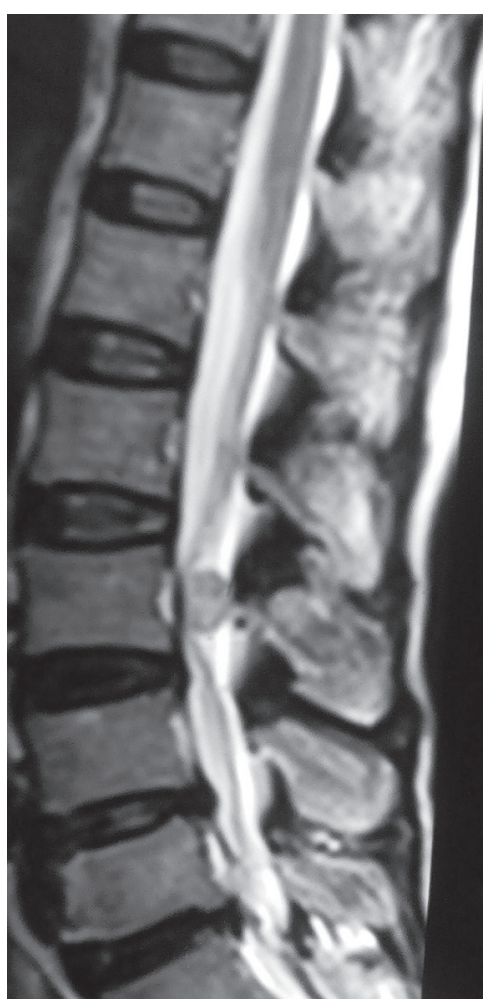

Figure 2: Magnetic resonance imaging lumbosacral spine, sagittal section, $\mathrm{T} 2 \mathrm{~W}$ image showing hypointense solitary lesion located at third lumbar vertebra level causing displacement of cauda equina nerve roots 


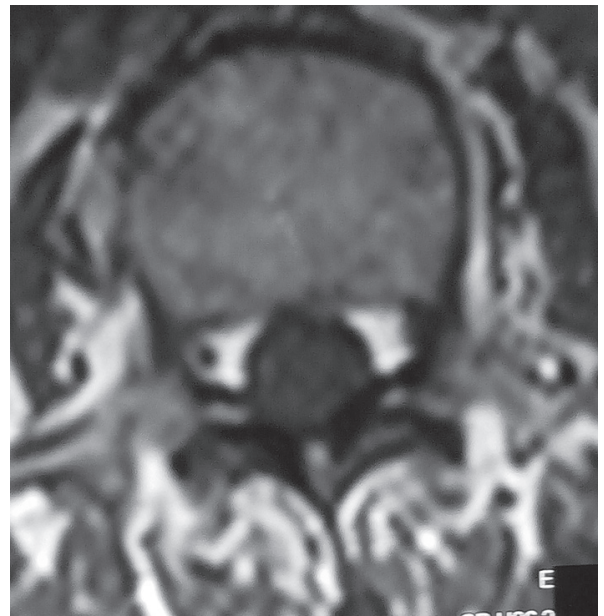

Figure 3: Magnetic resonance imaging, lumbosacral spine, axial section $\mathrm{T} 1 \mathrm{~W}$ image showing hypointense lesion at third lumbar vertebra

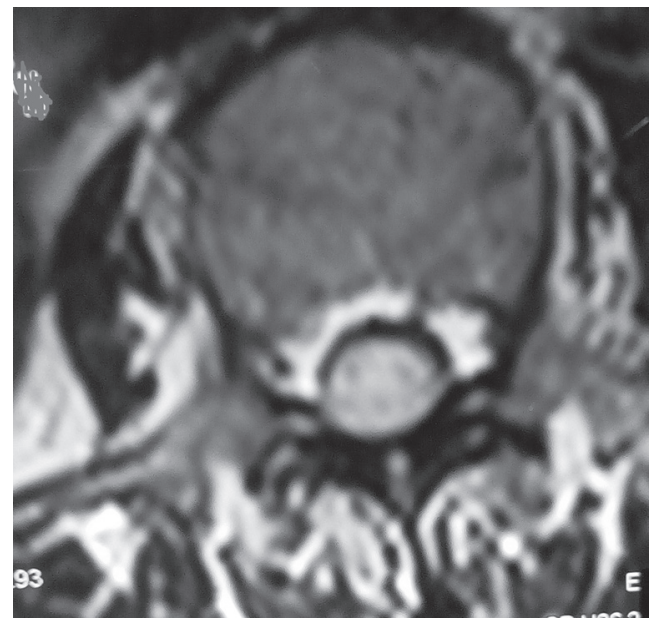

Figure 5: Magnetic resonance imaging, contrast study lumbosacral spine, axial section image showing uniformly brilliantly enhancing intradural mass lesion

bladder dysfunction are rare. Spinal paraganglioma presenting with endocrine manifestation is also rare but reported by Moran et al., Toyota et al., and Böker et al. ${ }^{[7,16,19]}$

Clinically relevant secretary activity of spinal paragangliomas cells, i.e., release of catecholamines, is a rare phenomenon, and however, can be induced by surgical manipulations of the tumor during surgery. ${ }^{[1,5]}$ It may be associated with syringomyelia or intramedullary cyst. ${ }^{[3,12]}$ Paraganglioma is pathologically considered as benign lesion with slow-growing mass possessing relatively low proliferative activity ${ }^{[11,18]}$ although malignant potentials are also occasionally reported by Blades et al. and Moran et al. ${ }^{[2,7]}$

Histologically, spinal paragangliomas are generally identical to paragangliomas in other locations. Some variants of classic paraganglioma, including monocytic metaphase, the presence of spindle cell component,

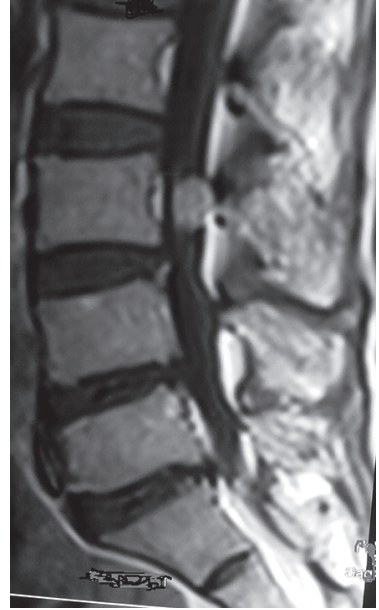

Figure 4: Magnetic resonance imaging, contrast study of lumbosacral spine, sagittal section image showing brilliantly enhancing intradural lesion at third lumbar vertebra placed intradurally

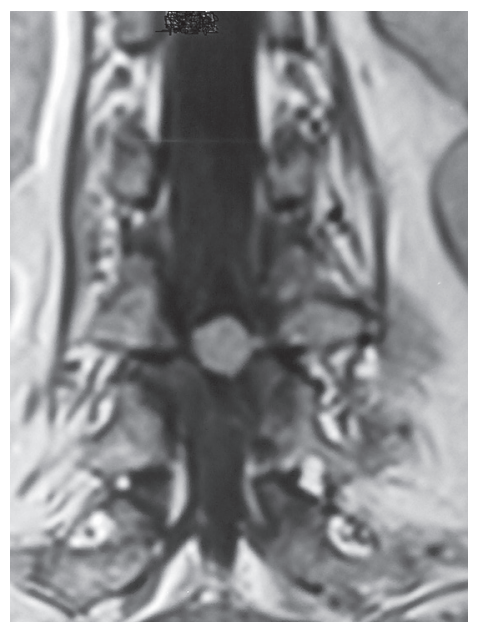

Figure 6: Magnetic resonance imaging lumbosacral spine contrast study, coronal section image showing brilliantly enhancing paraganglioma

melanin pigment, and ganglion cells have been observed in spinal paragangliomas. The histological picture of the current case was consistent, with alveolar "zellballen" pattern, which is typical of paragangliomas as other located in the other part of the body. Immunopositivity for neuroendocrine markers - chromogranin A, synaptophysin, and neuronal specific enolase in chief cells and positive reaction for S-100 protein in sustentacular cells supported the histological diagnosis in the current case. To conclude, the spinal paraganglioma is extremely rare benign neoplasm. Surgical resection is usually considered as standard management. Spinal paraganglioma should be considered as one of the differential diagnoses of spinal intradural tumors, which is showing intense enhancement on gadolinium-enhanced MRI scan.

\section{Financial support and sponsorship}

Nil. 


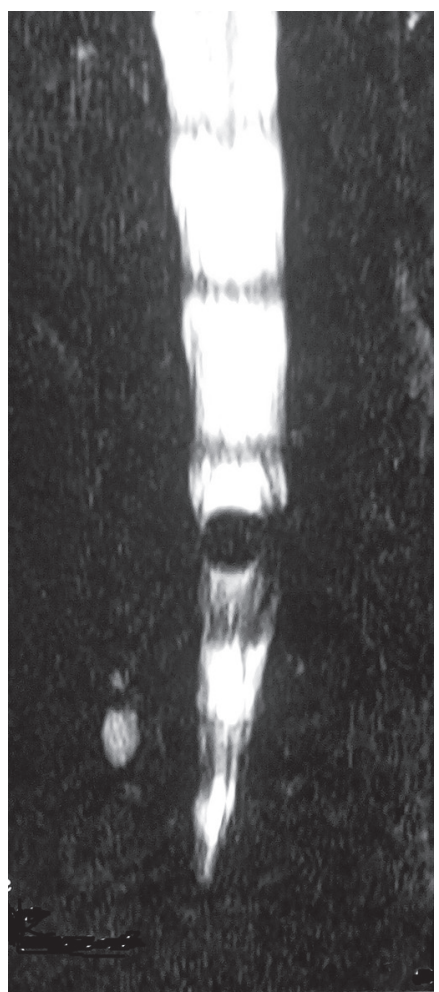

Figure 7: Magnetic resonance imaging myelography showing centrally placed lesion with displaced nerve roots

\section{Conflicts of interest}

There are no conflicts of interest.

\section{Guru Dutta Satyarthee, Kanwaljit Garg, Sachin A. Borkar}

Department of Neurosurgery, Neurosciences Centre, AIIMS, New Delhi, India

Address for correspondence: Dr. Guru Dutta Satyarthee, Department of Neurosurgery, Neuroscience Centre, All India Institute of Medical Sciences, New Delhi, India. E-mail: duttaguru2002@yahoo.com

\section{REFERENCES}

1. Anderson JR, Gullan RW. Paraganglioma of the cauda equina: A case report. J Neurol Neurosurg Psychiatry 1987;50:100-3.

2. Blades DA, Hardy RW, Cohen M. Cervical paraganglioma with subsequent intracranial and intraspinal metastases. Case report. J Neurosurg 1991;75:320-3.

3. Nagarjun MN, Savardekar AR, Kishore K, Rao S, Pruthi N, Rao MB. Apoplectic presentation of a cauda equina paraganglioma. Surg Neurol Int 2016;7:37.

4. Hilmani S, Ngamasata T, Karkouri M, Elazahri A. Paraganglioma of the filum terminale mimicking neurinoma: Case report. Surg Neurol Int 2016;7 Suppl 5:S153-5.

5. Kamalian N, Abbassioun K, Amirjamshidi A, Shams-Shahrabadi M. Paraganglioma of the filum terminale internum. Report of a case and review of the literature. J Neurol 1987;235:56-9.

6. Lázaro B, Klemz M, Flores MS, Landeiro JA. Malignant paraganglioma with vertebral metastasis: Case report. Arq Neuropsiquiatr 2003;61:463-7.

7. Moran CA, Rush W, Mena H. Primary spinal paragangliomas: A clinicopathological and immunohistochemical study of 30 cases. Histopathology 1997;31:167-73.

8. Dillard-Cannon E, Atsina KB, Ghobrial G, Gnass E, Curtis MT, Heller J. Lumbar paraganglioma. J Clin Neurosci 2016;30:149-51.

9. Coles CP, Alexander DI, Gross M, Holness RO, Covert AA, Murray SK. Intraosseous paraganglioma of the sacrum: A case report. Can J Surg 2000;43:137-9.

10. Boncoeur-Martel MP, Lesort A, Moreau JJ, Labrousse F, Roche I, Bouillet P, et al. MRI of paraganglioma of the filum terminale. J Comput Assist Tomogr 1996;20:162-5.

11. Sundgren $P$, Annertz $M$, Englund E, Strömblad LG, Holtås S. Paragangliomas of the spinal canal. Neuroradiology 1999;41:788-94.

12. Faro SH, Turtz AR, Koenigsberg RA, Mohamed FB, Chen CY, Stein H. Paraganglioma of the cauda equina with associated intramedullary cyst: MR findings. AJNR Am J Neuroradiol 1997; 18:1588-90.

13. Lamer S, Carlier RY, Parker F, Lacroix C, Larue F, de Latour B, et al. Paraganglioma of the cauda equina: MR findings. One case. J Neuroradiol 1997;24:215-7.

14. Roche PH, Figarella-Branger D, Regis J, Peragut JC. Cauda equina paraganglioma with subsequent intracranial and intraspinal metastases. Acta Neurochir (Wien) 1996;138:475-9.

15. Sonneland PR, Scheithauer BW, LeChago J, Crawford BG, Onofrio BM. Paraganglioma of the cauda equina region. Clinicopathologic study of 31 cases with special reference to immunocytology and ultrastructure. Cancer 1986;58:1720-35.

16. Toyota B, Barr HW, Ramsay D. Hemodynamic activity associated with a paraganglioma of the cauda equina. Case report. J Neurosurg 1993;79:451-5.

17. Wager M, Lapierre F, Blanc JL, Listrat A, Bataille B. Cauda equina tumors: A French multicenter retrospective review of 231 adult cases and review of the literature. Neurosurg Rev 2000;23:119-29.

18. Wippold FJ $2^{\text {nd }}$, Smirniotopoulos JG, Pilgram TK. Lesions of the cauda equina: A clinical and pathology review from the Armed Forces Institute of Pathology. Clin Neurol Neurosurg 1997;99:229-34.

19. Böker DK, Wassmann H, Solymosi L. Paragangliomas of the spinal canal. Surg Neurol 1983;19:461-8.

20. Pigott TJ, Lowe JS, Morrell K, Kerslake RW. Paraganglioma of the cauda equina. Report of three cases. J Neurosurg 1990;73:455-8.

21. Hamilton MA, Tait D. Metastatic paraganglioma causing spinal cord compression. Br J Radiol 2000;73:901-4.

This is an open access article distributed under the terms of the Creative Commons Attribution-NonCommercial-ShareAlike 3.0 License, which allows others to remix, tweak, and build upon the work non-commercially, as long as the author is credited and the new creations are licensed under the identical terms.

\begin{tabular}{|c|c|}
\hline \multicolumn{2}{|c|}{ Access this article online } \\
\hline Quick Response Code: & $\begin{array}{l}\text { Website: } \\
\text { www.ruralneuropractice.com }\end{array}$ \\
\hline 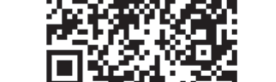 & $\begin{array}{l}\text { DOI: } \\
\text { 10.4103/jnrp.jnrp_477_16 }\end{array}$ \\
\hline
\end{tabular}

How to cite this article: Satyarthee GD, Garg K, Borkar SA. Paraganglioma of the filum-terminale: An extremely uncommon neuroendocrine neoplasm located in spine. J Neurosci Rural Pract 2017;8:490-3.

(C) 2017 Journal of Neurosciences in Rural Practice | Published by Wolters Kluwer - Medknow 